\title{
High Tidal Volume Ventilation Activates Smad2 and Upregulates Expression of Connective Tissue Growth Factor in Newborn Rat Lung
}

\author{
SHU WU, LETIZIA CAPASSO, ANDREA LESSA, JINGHONG PENG, KALYANI KASISOMAYAJULA, MARIA RODRIGUEZ, \\ CLEIDE SUGUIHARA, AND EDUARDO BANCALARI
}

Department of Pediatrics [S.W., L.C., A.L., J.P., K.K., C.S., E.B.], Division of Neonatology and Department of Pathology [M.R.], University of Miami School of Medicine, Miami, Florida

\begin{abstract}
High tidal volume $\left(V_{\mathrm{T}}\right)$ ventilation plays a key role in ventilator induced lung injury and bronchopulmonary dysplasia. However, little is known about the effect of high $V_{\mathrm{T}}$ on expression of growth factors that are critical to lung development. In a previous study, we demonstrated that connective tissue growth factor (CTGF) inhibits branching morphogenesis. In this study, we investigated the effect of high $V_{\mathrm{T}}$ on CTGF expression in newborn rat lungs. Newborn rats were ventilated with normal $V_{\mathrm{T}}(10 \mathrm{~mL} / \mathrm{kg})$ or high $V_{\mathrm{T}}(25$ $\mathrm{mL} / \mathrm{kg}$ ) for $6 \mathrm{~h}$. Nonventilated animals served as controls. We found that high $V_{\mathrm{T}}$ upregulated CTGF expression. To identify the potential signaling pathways mediating high $V_{\mathrm{T}}$ induction of CTGF, newborn rats were ventilated with high $V_{\mathrm{T}}$ for 1 or $3 \mathrm{~h}$. Temporal expression of TGF- $\beta \mathrm{s}$, p-Smad2, Smad7, and CTGF was analyzed. High $V_{\mathrm{T}}$ ventilation did not change gene expression of TGF- $\beta$ s and Smad7 but induced rapid and sustained expression of $\mathrm{p}-\mathrm{Smad} 2$ that precedes increased CTGF expression. CTGF and p-Smad2 were localized in bronchiolar epithelial cells, alveolar walls and septa. These data suggest that high $V_{\mathrm{T}}$ ventilation activates the Smad2 pathway, which may be responsible for downstream induction of CTGF expression in newborn rat lungs. (Pediatr Res 63: 245-250, 2008)
\end{abstract}

$\mathrm{M}$ echanical ventilation is essential for managing prematurely born infants with respiratory failure. However, ventilation with high tidal volume $\left(V_{\mathrm{T}}\right)$ can lead to ventilator induced lung injury (VILI) and bronchopulmonary dysplasia (BPD) (1-3). The lung pathology of BPD is characterized by fewer and larger alveoli, dysmorphic and decreased capillary network, and variable interstitial fibrosis, suggesting abnormal lung development and injury repair processes $(4,5)$. Most of the studies in VILI and BPD have been focused on high $V_{\mathrm{T}}$ induced lung proinflammatory response (6-9). Little is known about the effect of high $V_{\mathrm{T}}$ on expression of growth factors that are key to lung development and injury repair in neonatal lungs.

Connective tissue growth factor (CTGF) belongs to the CCN family of early gene products with a high degree of amino acid sequence homology and 38 conserved cysteine

\section{Received August 8, 2007; accepted November 1, 2007.}

Correspondence: Shu Wu, M.D., Department of Pediatrics, Division of Neonatology, University of Miami School of Medicine, PO Box 016960, Miami, FL 33101; e-mail: swu2@med.miami.edu.

This work was supported by funding from NIH grant K08 HD046582, the Project New Born University of Miami, and a grant from Bank of America Charitable Foundation, INC. residues $(10,11)$. CTGF promotes fibroblast proliferation, extracellular matrix (ECM) production, myofibroblast differentiation, and cell adhesion and migration (12-16). CTGF is a potent profibrotic cytokine and its mRNA and protein levels have been correlated with the degree of lung fibrosis in bleomycin-treated mice and in human fibrotic lung disorders (17-19). Previous studies have demonstrated that mechanical stress drastically induces CTGF expression in cultured fibroblasts $(20,21)$. CTGF is closely linked to TGF- $\beta$. Studies have demonstrated that TGF- $\beta$ is a major inducer of CTGF expression in a variety of tissues and organs including the lung (11,22-24). Activation of the Smad pathway plays a key role in TGF- $\beta$ induction of CTGF expression $(25,26)$. TGF- $\beta$ stimulation of fibroblast proliferation, collagen synthesis, and myofibroblast differentiation is mediated via a CTGFdependent pathway (13-15). Recent data suggest that CTGF plays a role in lung development and neonatal lung injury. Using an embryonic lung explant model, we have demonstrated that endogenous expression of CTGF and TGF- $\beta$ induced CTGF expression is mediated via the Smad2 pathway (27). Furthermore, addition of recombinant CTGF into the culture medium inhibited branching morphogenesis (27). A recent study in a neonatal rat model showed that hyperoxia exposure increased CTGF mRNA and protein expression, which precedes the fibrotic phase of lung injury (28). These data suggest that CTGF is a negative regulator for lung morphogenesis and may play a role in hyperoxia-induced lung injury and fibrosis in the neonatal lung. However, the role of CTGF in high $V_{\mathrm{T}}$ induced lung injury in neonates is unknown.

We hypothesized that high $V_{\mathrm{T}}$ ventilation induces CTGF expression in newborn rat lungs. To test this hypothesis, newborn rats were ventilated with normal or high $V_{\mathrm{T}}$. CTGF mRNA and protein expression were evaluated in the lungs of these animals and compared with control nonventilated animals. Temporal expression of TGF- $\beta$ s, phosphorylated Smad2 (p-Smad2), a key intracellular transducer of TGF- $\beta$ responses,

Abbreviations: BPD, bronchopulmonary dysplasia; CTGF, connective tissue growth factor; ECM, extracellular matrix; $\mathbf{E}_{\mathbf{T}} \mathbf{C O}_{2}$, end-tidal $\mathrm{CO}_{2}$; GAPDH, glyceraldehyde-3-phosphate dehydrogenase; HE, hematoxylin and eosin; PEEP, positive end-expiratory pressure; PIP, peak inspiratory pressure; p-Smad2, phosphorylated Smad2; VILI, ventilator induced lung injury; $V_{\mathrm{T}}$, tidal volume 
and Smad7, a inhibitory Smad was also investigated to identify the potential signal transduction pathway mediating high $V_{\mathrm{T}}$ induced CTGF expression in newborn rat lungs.

\section{MATERIALS AND METHODS}

Animal preparation and ventilator protocol. The animal protocol was approved by the Animal Care and Use Committee of the University of Miami School of Medicine. Newborn Sprague-Dawley rats (7-14 d old) were anesthetized by intraperitoneal injection of ketamine $(40 \mathrm{mg} / \mathrm{kg})$ and xylazine $(4 \mathrm{mg} / \mathrm{kg})$ and tracheotomized. To compare the effects of normal $V_{\mathrm{T}}$ and high $V_{\mathrm{T}}$ on expression of CTGF, animals were randomly assigned to one of the following three groups:

Group 1: control (no-ventilation)

Group 2: ventilation with normal $V_{\mathrm{T}}(10 \mathrm{~mL} / \mathrm{kg})$ for $6 \mathrm{~h}$

Group 3: ventilation with high $V_{\mathrm{T}}(25 \mathrm{~mL} / \mathrm{kg})$ for $6 \mathrm{~h}$

The normal $V_{\mathrm{T}}$ and high $V_{\mathrm{T}}$ were based on a recent study of VILI in newborn rats (9). To determine the potential signal transduction pathways mediating CTGF expression, two additional groups of animals were studied:

Group 4: ventilation with high $V_{\mathrm{T}}(25 \mathrm{~mL} / \mathrm{kg})$ for $1 \mathrm{~h}$

Group 5: ventilation with high $V_{\mathrm{T}}(25 \mathrm{~mL} / \mathrm{kg})$ for $3 \mathrm{~h}$

The animals were ventilated using a time-cycled ventilator (Sechrist Infant Ventilator model iv-100B, Anaheim, CA) with positive end-expiratory pressure (PEEP) of $3 \mathrm{~cm} \mathrm{H}_{2} \mathrm{O}$, inspiratory time of $0.2 \mathrm{~s}$, and $40 \%$ oxygen $\left(\mathrm{O}_{2}\right)$. Airflow was measured by a heated pneumotachograph (Model 8430B, flow range $0-3 \mathrm{~L} / \mathrm{min}$, linearity $0.2 \%$, Hans Rudolph, Inc. Kansas City, MI) placed between the tracheostomy tube and the ventilator circuit. The differential pressure output from the pneumotachograph was measured with a transducer (MP45, Validyne Engineering Co., Northridge, CA) and amplified by a pressure amplifier (Gould Instrument, Cleveland, $\mathrm{OH}$ ). The flow signal was electronically integrated to obtain $V_{\mathrm{T}}$ as described before (29). The peak inspiratory pressure (PIP) was adjusted to maintain a $V_{\mathrm{T}}$ in the desired range. The end-tidal $\mathrm{CO}_{2}\left(\mathrm{E}_{\mathrm{T}} \mathrm{CO}_{2}\right)$ was measured intermittently (every $30 \mathrm{~min}$ ) by a Micro-Capnometer (Columbus Instrument, Columbus, $\mathrm{OH}$ ) via the side port of the tracheostomy tube and was maintained at the same level for normal and high $V_{\mathrm{T}}$ groups by adjusting the ventilator rate and dead space. Heart rate, airflow, $V_{\mathrm{T}}$, PIP, and PEEP were monitored continuously throughout the experiments. Body temperature was continuously monitored with a rectal thermal probe (Yellow Springs Instrument Co., Yellow Springs, OH), and maintained within the normal range for age $\left(35.8-36.2^{\circ} \mathrm{C}\right)$ by using a servo-controlled radiant warmer. Control animals breathed air and received anesthesia and tracheotomy as described before euthanasia. At the end of the experiment, animals were euthanized with an overdose of pentobarbital and lungs were removed for subsequent analysis.

Lung histology. The left lungs from control and $6 \mathrm{~h}$ ventilated animals were infused with $4 \%$ paraformaldehyde via a tracheal catheter under $20 \mathrm{~cm}$ $\mathrm{H}_{2} \mathrm{O}$ pressure and fixed overnight at $4{ }^{\circ} \mathrm{C}$. Fixed lung tissues were paraffinembedded and $5 \mu \mathrm{m}$ sections were stained by the standard hematoxylin and eosin (HE) method. Lung histology was examined by a pathologist unaware of the experimental conditions.

RNA isolation and quantitative real-time (RT)-PCR. Total RNA was isolated from frozen right lung tissue using Trizol reagent (Invitrogen, Carsbad, CA) and then treated with DNase to remove possible DNA contamination. Two micrograms of total RNA was reverse-transcribed in a $20 \mu \mathrm{L}$ reaction by using a first-strand cDNA synthesis kit according to the manufacturer's protocol (Invitrogen, Carsbad, CA). The quantitative real-time RT-PCR was performed on a Light-cycler (Roche, Indianapolis, IN). Each reaction included diluted first-strand cDNA, rat IL-6, TNF- $\alpha$, CTGF, TGF$\beta 1$, TGF- $\beta 2$, TGF- $\beta 3$, or glyceraldehyde-3-phosphate dehydrogenase (GAPDH) primers, and $\mathrm{RT}^{2}$ Real-Time PCR SYBR Green master mix according to the manufacturer's instructions (Superarray, Frederick, MD). Real-time RT-PCR conditions were $95^{\circ} \mathrm{C}$ for $15 \mathrm{~min}$, followed by 40 cycles of $95^{\circ} \mathrm{C}$ for $30 \mathrm{~s}, 55^{\circ} \mathrm{C}$ for $30 \mathrm{~s}$, and $72^{\circ} \mathrm{C}$ for $30 \mathrm{~s}$. RNase-free water was used as a negative control. For each target gene, a standard curve was established by performing a series dilution of first-strand cDNA. The mRNA expression levels of these factors were determined from the standard curve and normalized to GAPDH.

Northern blot analysis. Twenty microgram of total RNA from each lung sample was electrophoresed on $1.2 \%$ agarose gel containing formaldehyde and transferred to a nylon membrane. A 1 kb human CTGF cDNA fragment that has been cloned into the $\mathrm{pRc} / \mathrm{CMV}$ plasmid was used to generate radiolabeled CTGF probe. A 497 bp mouse GAPDH cDNA was prepared by RT-PCR using primers 5'-ACCACAGTCCATGCCATCAC-3' (position
593-613) and 5'-TCCACCACCCTGTTGATGTA-3' (position 1090-1110). The CTGF and GAPDH cDNAs were radiolabeled with $\left[{ }^{32} \mathrm{P}\right] \mathrm{dCTP}$ using the DNA labeling kit and purified using Quick Spin Columns (Amersham Biosciences, Piscataway, NJ). The hybridization was first carried out with $\left[{ }^{32} \mathrm{P}\right]$-labeled CTGF probe, then stripped and rehybridized with $\left[{ }^{32} \mathrm{P}\right]$-labeled GAPDH probe as described (30). The intensities of mRNA bands on the autoradiography were quantified by Quantity One Imaging Analysis Program (Bio-Rad, Richmond, CA). The CTGF mRNA levels were determined after normalization to GAPDH.

Western blot analysis. Total protein was extracted from frozen right lung tissues with a lysis buffer from Active Motif according to the manufacturer's protocol (Carsbad, CA). The protein concentrations were measured by BCA protein assay using commercial kits from Pierce Biotechnology Inc (Rockford, IL). Seventy-five micrograms of total protein was fractionated by SDS-PAGE on a $10 \%$ Tris-glycine precast gel (Bio-Rad) and then transferred to a nitrocellulose membrane (Amersham). The membrane was incubated with a primary antibody for CTGF (1:1000 dilution), total Smad2/3 (1:500 dilution), Smad7 (1:500) (Santa Cruz Biotechnology Inc, Santa Cruz, CA), p-Smad2 (1:500 dilution) (Chemicon, Temecula, CA) or 1:10000 diluted mouse anti- $\beta$-actin antibody (Sigma Chemical Co., St. Louis, MO) overnight at $4^{\circ} \mathrm{C}$, then incubated for $1 \mathrm{~h}$ at room temperature with the respective HRP-conjugated secondary antibodies. Antibody bond proteins were detected using ECL chemiluminescence method (Amersham). The intensities of protein bands were quantified by Quantity One Imaging Analysis Program. The CTGF and Smad7 levels were determined after normalization to $\beta$-actin and $\mathrm{p}$-Smad2 levels were normalized to total Smad2/3.

Immunohistochemistry. Localization of CTGF, p-Smad2, or total Smad2/3 protein expression was determined by immunostaining with a rabbit CTGF antibody (Torrey Pines Biolabs, Huston, TX), a rabbit p-Smad2 antibody (Chemicon) or a goat total Smad2/3 antibody (Santa Cruz). The dilution for all three antibodies was 1:1000. These antibodies are specific and have been used in many published studies $(31,32)$. Nonimmune IgG was used as the negative control. The antibody bond positive cells were detected with a biotinylated secondary antibody, streptavidin-biotin-peroxidase complexes and DAB substrate (Vector, Burlingame, CA).

Statistical analysis. Data are presented as mean \pm SD. Comparisons were performed using one-way ANOVA followed by the Student-Newman-Keuls test. A $p$ value of less than 0.05 was considered significant.

\section{RESULTS}

Physiologic data. As shown in Table 1, the control rats and 6-h ventilated animals had similar age and weight. As expected, the PIP for the high $V_{\mathrm{T}}$ group was significantly higher than the PIP for the normal $V_{\mathrm{T}}$ group. The $\mathrm{E}_{\mathrm{T}} \mathrm{CO}_{2}$ was in the same range for both normal and high $V_{\mathrm{T}}$ ventilated groups.

Lung histology. The most striking finding was severe overdistension of the distal airspaces and thinning of the alveolar septum seen in the high $V_{\mathrm{T}}$ ventilated lungs (Fig. 1). The normal $V_{\mathrm{T}}$ lungs appeared similar to the control lungs.

Expression of IL-6 and TNF- $\alpha$ mRNA. Ventilation with normal or high $V_{\mathrm{T}}$ for $6 \mathrm{~h}$ did not change mRNA expression of TNF- $\alpha$ compared with the control group (data not shown). However, high $V_{\mathrm{T}}$ ventilation resulted in near threefold increase in IL-6 mRNA expression $(3.12 \pm 1.72)$ compared with the control group $(1.11 \pm 0.42)$ and normal $V_{\mathrm{T}}$ group $(1.45 \pm 0.5)(p=0.011)$.

Expression of CTGF mRNA. When compared with the control group, ventilation with normal $V_{\mathrm{T}}$ for $6 \mathrm{~h}$ did not affect

Table 1. Physiological data

\begin{tabular}{lrlc}
\hline & \multicolumn{1}{c}{ Control } & Normal $V_{\mathrm{T}}$ & \multicolumn{1}{c}{ High $V_{\mathrm{T}}$} \\
\hline Age (d) & $10 \pm 1.8$ & $11.2 \pm 2.1$ & $10 \pm 1.4$ \\
Weight $(\mathrm{g})$ & $23.1 \pm 5.6$ & $26.1 \pm 8.1$ & $21.5 \pm 5.6$ \\
$\mathrm{PIP}\left(\mathrm{cm} \mathrm{H} \mathrm{H}_{2} \mathrm{O}\right)$ & & $12.0 \pm 0.99$ & $17.5 \pm 3.45^{*}$ \\
$\mathrm{E}_{\mathrm{T}} \mathrm{CO}_{2}(\mathrm{~mm} \mathrm{Hg})$ & & $40.3 \pm 0.81$ & $39.5 \pm 2.31$ \\
\hline
\end{tabular}

Data are mean \pm SD from seven animals per group.

$* p<0.002$ high $V_{\mathrm{T}} v s$. normal $V_{\mathrm{T}}$. 

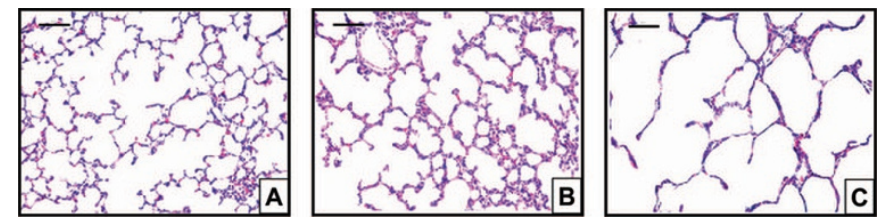

Figure 1. Histology of control, normal, and high $V_{\mathrm{T}}$ ventilated lungs. Lung tissue sections from control $(A)$, normal $V_{\mathrm{T}}(B)$, and high $V_{\mathrm{T}}(C)$ ventilation for $6 \mathrm{~h}$ were stained by standard $\mathrm{H} \& \mathrm{E}$ method. The histology of normal $V_{\mathrm{T}}$ lungs was similar to that of controls. Severe alveolar over-distension and thinning of the septa were noticed in the high $V_{\mathrm{T}}$ ventilated lungs. Images were taken under $200 \times$ magnifications. Bars $=40 \mu \mathrm{m}$.
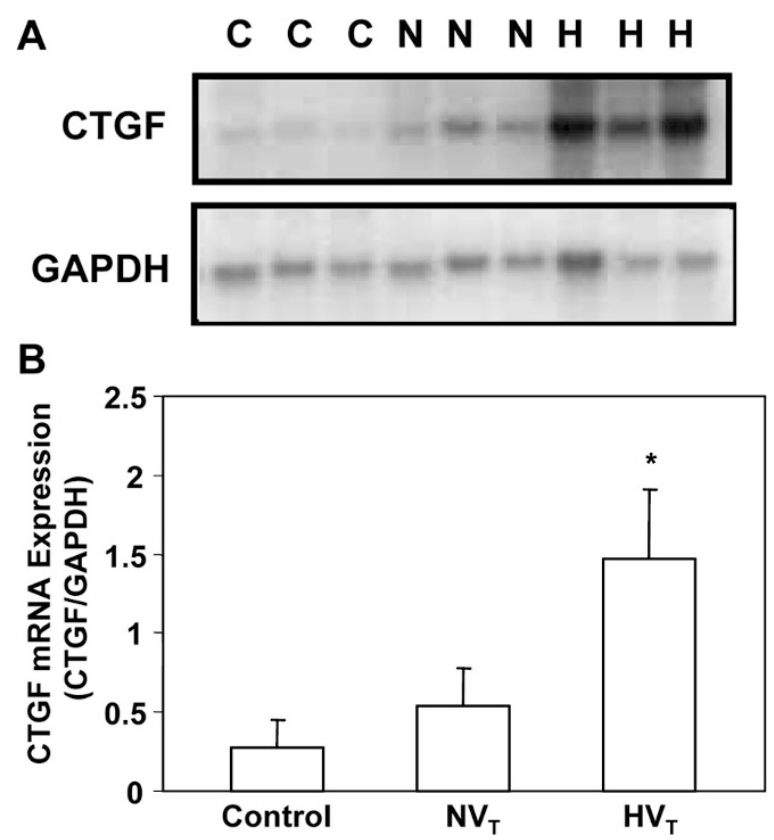

Figure 2. Induction of CTGF mRNA expression by mechanical ventilation is $V_{\mathrm{T}-}$ dependent. $A$, Representative autoradiographs from Northern blot analysis. C: control; N: normal $V_{\mathrm{T}}$ for $6 \mathrm{~h}$ : H: high $V_{\mathrm{T}}$ for $6 \mathrm{~h}$. $B$, Densitometric quantification of Northern blot analysis. Data are mean $\pm \mathrm{SD}$ from seven animals in each group. Increased CTGF mRNA was detected in high $V_{\mathrm{T}}$ ventilated lungs. ${ }^{*} p<0.001$ compared with control and normal $V_{\mathrm{T}}$ ventilation.

CTGF mRNA expression. However, ventilation with high $V_{\mathrm{T}}$ for $6 \mathrm{~h}$ significantly upregulated CTGF mRNA expression compared with both control and normal $V_{\mathrm{T}}$ groups (Fig. 2).

Expression of CTGF protein. Consistent with CTGF mRNA expression, normal $V_{\mathrm{T}}$ ventilation for $6 \mathrm{~h}$ did not change CTGF protein expression compared with the control group. However, high $V_{\mathrm{T}}$ ventilation for $6 \mathrm{~h}$ significantly increased CTGF protein expression compared with both control and normal $V_{\mathrm{T}}$ groups (Fig. 3).

Localization of CTGF protein expression. As shown in Fig. 4, CTGF protein was sparsely detected with moderate intensity in alveolar walls and septa, and weak intensity in bronchiolar epithelial cells in control and normal $V_{\mathrm{T}}$ ventilated lungs (Fig. 4A,B). However, CTGF protein was abundantly detected with strong intensity in alveolar walls and septa, and bronchiolar epithelial cells in high $V_{\mathrm{T}}$ ventilated lungs (Fig. $4 C$ ).

Temporal effect of high $V_{T}$ on mRNA expression of TGF$\beta 1, T G F-\beta 2, T G F-\beta 3$, and $C T G F$. There was no significant difference in mRNA expression of the three TGF- $\beta$ s among control and the groups ventilated with high $V_{\mathrm{T}}$ (Table 2). High
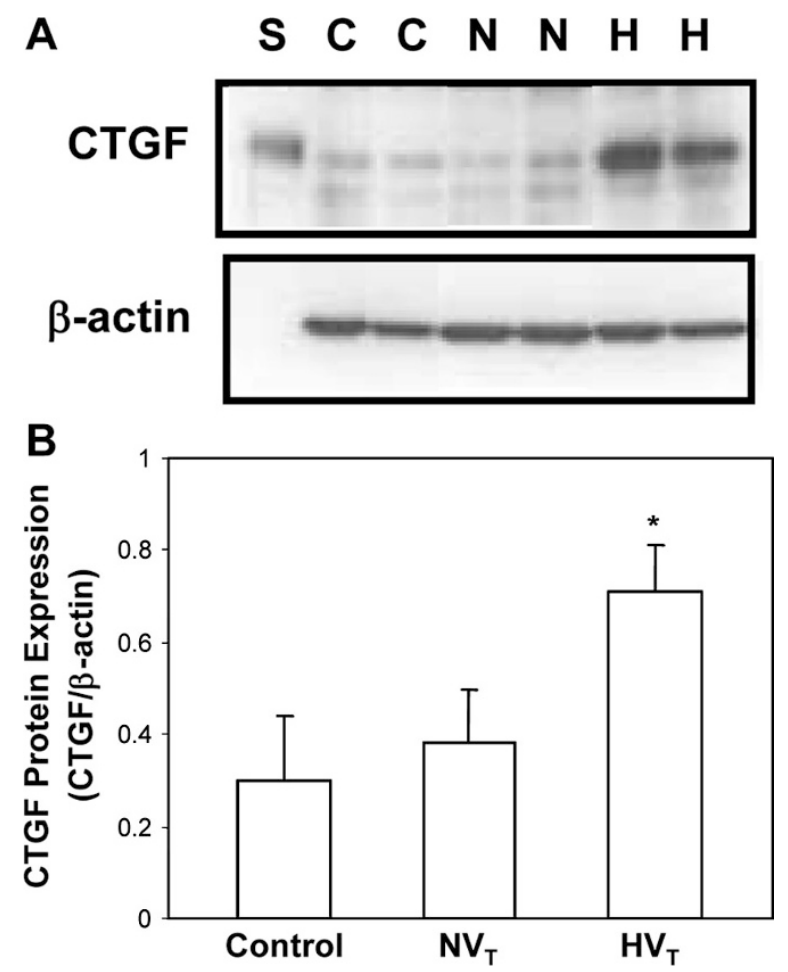

Figure 3. High $V_{\mathrm{T}}$ ventilation upregulates CTGF protein expression. CTGF protein was detected by Western blot with a CTGF specific antibody in control, normal $V_{\mathrm{T}}$ and high $V_{\mathrm{T}}$ ventilated lungs $(6 \mathrm{~h})$ and normalized by $\beta$-actin. $A$, Representative Western blot images. S: CTGF standard. $B$, Densitometric quantification of Western blot analysis. Results are mean $\pm \mathrm{SD}$ from control $(n=6)$, normal $V_{\mathrm{T}}(n=5)$ and high $V_{\mathrm{T}}(n=4)$ groups. High $V_{\mathrm{T}}$ increased CTGF protein expression compared with both control and normal $V_{\mathrm{T}}$ group. ${ }^{*} p<0.001$.
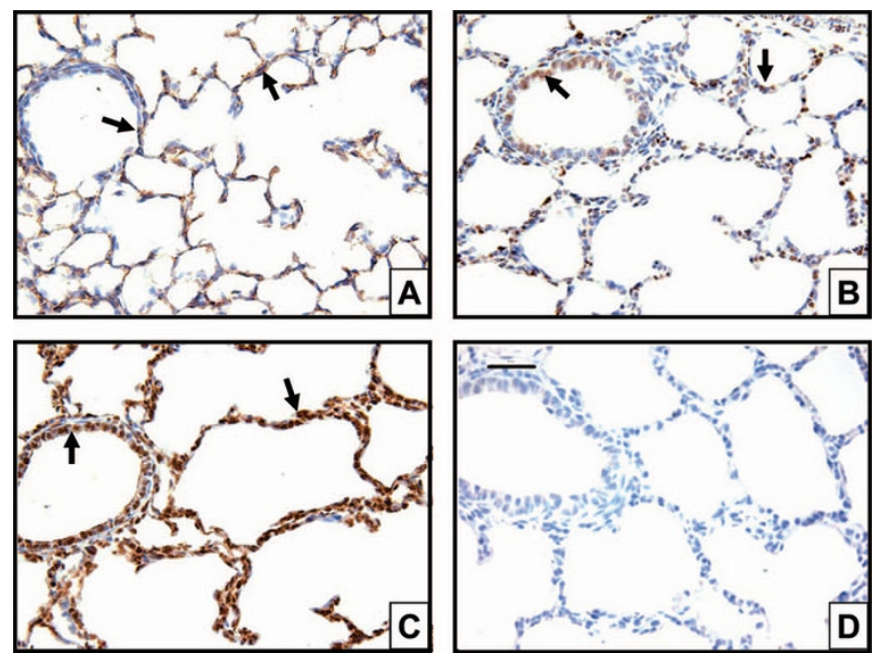

Figure 4. Localization of CTGF protein by immunohistochemistry. Lung tissue sections were immunostained with a CTGF specific antibody. CTGF positive cells (brown color) are indicated by arrows. $A$, control; $B$, normal $V_{\mathrm{T}}$ ventilation (6 h); $C$, high $V_{\mathrm{T}}$ ventilation $(6 \mathrm{~h}) ; D$, negative control stained with nonimmune IgG. CTGF was detected with stronger intensity and more abundance in high $V_{\mathrm{T}}$ ventilated lungs when compared with control and normal $V_{\mathrm{T}}$ ventilated lungs. Images were taken under $400 \times$ magnifications. Bar $=20 \mu \mathrm{m}$.

$V_{\mathrm{T}}$ ventilation for 1 or $3 \mathrm{~h}$ did not change CTGF mRNA expression, but increased CTGF mRNA expression at $6 \mathrm{~h}$ (Table 2) which was also demonstrated by Northern blot analysis described above (Fig. 2). Active TGF- $\beta 1$ was mea- 
Table 2. Gene expression of TGF- $\beta 1, T G F-\beta 2, T G F-\beta 3$ and $C T G F$

\begin{tabular}{lcccc}
\hline & & \multicolumn{4}{c}{ Ventilation duration (h) } \\
\cline { 3 - 5 } Gene & Control & 1 & 3 & 6 \\
\hline TGF- $\beta 1$ & $0.016 \pm 0.011$ & $0.017 \pm 0.006$ & $0.015 \pm 0.001$ & $0.013 \pm 0.007$ \\
TGF- $\beta 2$ & $0.024 \pm 0.009$ & $0.013 \pm 0.005$ & $0.014 \pm 0.011$ & $0.019 \pm 0.004$ \\
TGF- $\beta 3$ & $0.022 \pm 0.011$ & $0.017 \pm 0.003$ & $0.018 \pm 0.007$ & $0.019 \pm 0.010$ \\
CTGF & $0.047 \pm 0.015$ & $0.080 \pm 0.003$ & $0.078 \pm 0.001$ & $0.220 \pm 0.012 * \dagger$ \\
\hline
\end{tabular}

mRNA levels were determined by real-time RT-PCR and normalized by GAPDH. Data are mean \pm SD from six animals per group.

$* p<0.001$ compared with control group.

$\dagger p<0.002$ compared with 1 and $3 \mathrm{~h}$ ventilated groups.

sured by ELISA (without activation) in protein extracts from control and high $V_{\mathrm{T}}$ ventilated lungs and there was no difference among the groups (data not shown).

Expression of Smad7 and p-Samd2 in response to high $\mathbf{V}_{T}$ ventilation. Western blot analysis revealed that high $V_{\mathrm{T}}$ ventilation did not change Smad7 expression at any time point (control: $0.45 \pm 0.18 ; 1$ h: $0.48 \pm 0.07 ; 3$ h: $0.51 \pm 0.07 ; 6 \mathrm{~h}$ : $0.35 \pm 0.13, p=0.37)$. In contrast, high $V_{\mathrm{T}}$ ventilation induced rapid and sustained $\mathrm{p}-\mathrm{Smad} 2$ expression. As demonstrated in Fig. 5, high $V_{\mathrm{T}}$ significantly induced p-Smad2 expression as early as $1 \mathrm{~h}$ and this lasted for up to $6 \mathrm{~h}$. These results suggest that activation of Smad2 precedes CTGF induction by high $V_{\mathrm{T}}$. On immunohistochemistry, p-Smad2 was detected with weak intensity in alveolar walls and septa and bronchiolar epithelial cells in control lungs (Fig. 6A). However, p-Smad2 was detected with strong intensity in alveolar walls and septa, and bronchiolar epithelial cells in $6 \mathrm{~h}$ high $V_{\mathrm{T}}$ ventilated lungs (Fig. 6C). In contrast, total Smad-2 was detected with similar intensity in both control (Fig. 6B) and high $V_{\mathrm{T}}$ (Fig. $6 D$ ) ventilated lungs. The localization of pSmad2 was similar to that of CTGF.

\section{DISCUSSION}

The data of this study demonstrate that high $V_{\mathrm{T}}$ ventilation results in alveolar over-distension and upregulation of CTGF expression in newborn rat lungs. High $V_{\mathrm{T}}$ ventilation also induces rapid and sustained $\mathrm{p}-\mathrm{Smad} 2$ expression that precedes CTGF induction. To the best of our knowledge, this is the first report to demonstrate that high $V_{\mathrm{T}}$ ventilation is associated with activation of the Smad2 pathway and induction of CTGF expression in an in vivo neonatal animal model.

Despite the fact that aggressive ventilation is a major contributor in the pathogenesis of BPD, little is known about the molecular basis of volume induced lung injury in the immature lung. Although many studies in volume induced lung injury and BPD have been conducted in large animal models such as baboons and lambs, these animals are difficult to maintain and expensive $(33,34)$. The lung developmental stage of premature infants at risk for BPD is at the prealveolar stage, i.e., later canalicular and saccular stages $(35,36)$. The lungs of newborn rats are at the saccular stage that rapidly progresses to the alveolar stage in the first 2 weeks after birth $(37,38)$. Although the newborn rat lung is not surfactant deficient, its structure closely resembles the lung structure of
A

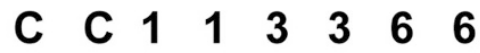

p-Smad2

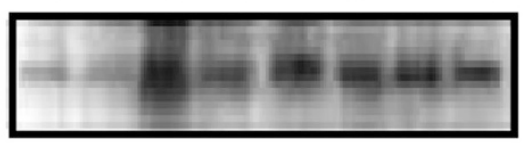

Smad2
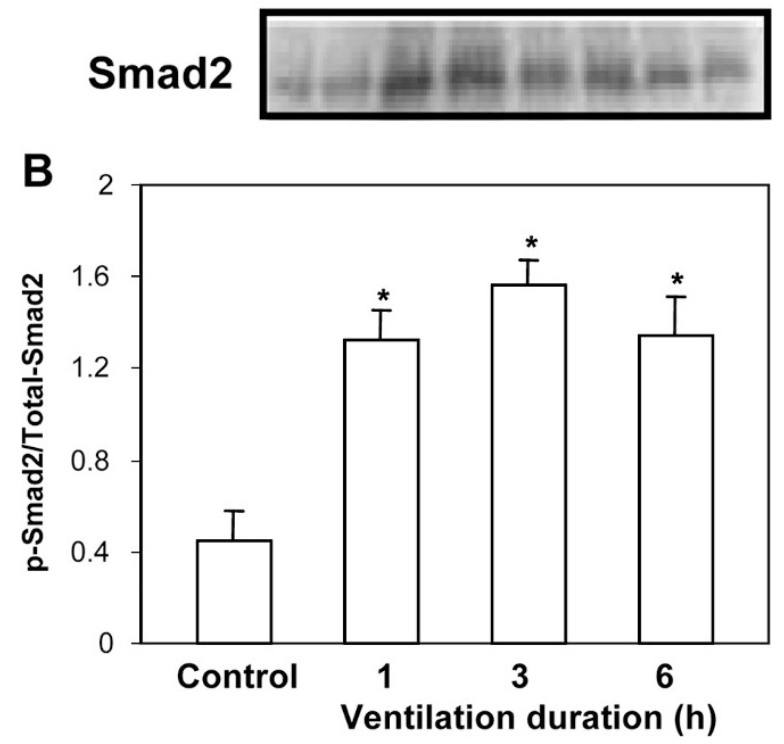

Figure 5. High $V_{\mathrm{T}}$ upregulates p-Smad2 expression. Expression of p-Smad2 was determined by Western blot analysis using a p-Smad2 specific antibody and normalized by total Smad2 in high $V_{\mathrm{T}}$ ventilated lungs. $A$, Representative Western blot images. Ventilation durations (h) are indicated on the top of the images. $B$, Densitometric quantification of Western blot analysis. Results are mean $\pm \mathrm{SD}$ from four animals in each group. High $V_{\mathrm{T}}$ ventilation increased p-Smad 2 expression from 1 to $6 \mathrm{~h}$ compared with control groups. ${ }^{*} p<0.001$.
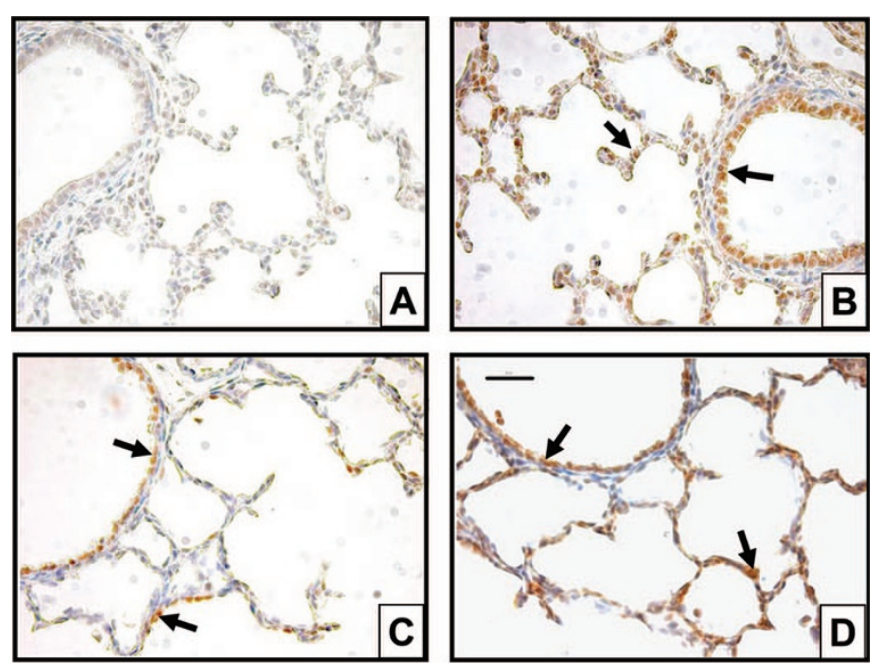

Figure 6. Localization of $\mathrm{p}-\mathrm{Smad} 2$. Lung tissue sections were stained with a p-Smad2 or a total Smad2 specific antibody. Positive cells for p-Smad2 and total Smad2 (brown color) are indicated by arrows. $A$, control stained with a p-Samd2 antibody; $B$, control stained with a total Smad2 antibody; $C$, high $V_{\mathrm{T}}$ ventilated lung stained with a $\mathrm{p}-\mathrm{Smad} 2$ antibody; $D$, high $V_{\mathrm{T}}$ ventilated lung stained with a total Smad2 antibody. P-Smad2 was strongly detected in bronchiolar epithelial cells and alveolar walls and septa in high $V_{\mathrm{T}}$ ventilated lungs. Images were taken under $400 \times$ magnifications. Bar $=20 \mu \mathrm{m}$.

premature infants at risk for BPD. We ventilated newborn rats (7-14 d) to investigate the effect of high $V_{\mathrm{T}}$ on lung expression of CTGF mRNA and protein. Consistent with our hypothesis, high $V_{\mathrm{T}}$ ventilation dramatically upregulated expression of 
CTGF mRNA and protein in newborn rat lung. In vitro studies have demonstrated that the CTGF gene is one of the most striking genes induced by mechanical stress $(20,21)$. CTGF is a multifunctional cytokine that promotes fibroblast proliferation, ECM production, and myofibroblast differentiation (1315). Overexpression of CTGF is associated with pulmonary fibrosis in adult human and animal models (17-19). Our data suggest that high $V_{\mathrm{T}}$ induced CTGF expression may cause profibrotic responses in the neonatal lung.

Previous studies have indicated that TGF- $\beta$ is a key inducer of CTGF expression in a variety of tissues and organs $(11,22-$ 24). In the present study, we took a step further to identify the potential upstream signal transduction pathway that mediates high $V_{\mathrm{T}}$ induced CTGF expression by focusing on the TGF- $\beta$ and Smad 2 axis. TGF- $\beta$ is a family of closely related peptides including TGF- $\beta 1$, TGF- $\beta 2$, and TGF- $\beta 3$. TGF- $\beta$ s initiate their action by binding to the TGF- $\beta$ receptors on the cell membrane and phosphorylate $\operatorname{Smad} 2 / 3$. The $\mathrm{p}-\mathrm{Smad} 2 / 3$ forms a complex with Smad4, translocates to the nucleus and binds to the target gene promoters to activate gene transcription (39). Smad7 is an inducible intracellular inhibitor that decreases Smad2/3 phosphorylation by blocking their access to TGF- $\beta$ receptors (39). Studies have indicated that TGF- $\beta$ activated Smad2/3 signal transduction pathway plays a key role in TGF- $\beta$ induction of CTGF expression $(25,26)$. We have previously shown that TGF- $\beta$ induces CTGF expression via the Smad2-dependent pathway during early embryonic lung development (27). In the present study, we examined the temporal relationship of Smad7, TGF- $\beta$ s, Smad2, and CTGF in response to high $V_{\mathrm{T}}$ ventilation in newborn rat lungs. We demonstrated that high $V_{\mathrm{T}}$ induction of CTGF expression is independent of decreased inhibitory Smad7. Although mRNA expression of TGF- $\beta$ s and active TGF- $\beta 1$ were not altered by high $V_{\mathrm{T}}$ at any time point, rapid and sustained expression of p-Smad2 was induced by high $V_{\mathrm{T}}$ and that preceded CTGF mRNA and protein expression. We also showed that p-Smad2 and CTGF are expressed in similar locations. These data demonstrate a temporal and spatial association of $\mathrm{p}-\mathrm{Smad} 2$ and CTGF expression suggesting that high $V_{\mathrm{T}}$ ventilation may activate the Smad2 signal transduction pathway which in turn results in upregulation of CTGF expression. Further studies are needed to determine whether high $V_{\mathrm{T}}$ activation of the Smad2 pathway is TGF- $\beta$-dependent or TGF- $\beta$-independent and if Smad2 activation mediates CTGF induction.

The present study was not designed to evaluate the effect of $\mathrm{O}_{2}$ concentration on CTGF expression. All animals were ventilated with $40 \% \mathrm{O}_{2}$ which is necessary to keep their hemodynamic function stable during the $6 \mathrm{~h}$ experiments. The fact that the animals ventilated with normal $V_{\mathrm{T}}$ did not exhibit any change in lung histology or CTGF expression suggests that the increased CTGF was caused by high $V_{\mathrm{T}}$ and not by $\mathrm{O}_{2}$.

We did not measure arterial blood gases due to the difficulty to obtain sufficient blood for such analysis. However, we closely monitored the $\mathrm{E}_{\mathrm{T}} \mathrm{CO}_{2}$, which was kept in the same range between the normal $V_{\mathrm{T}}$ and high $V_{\mathrm{T}}$ groups by adjusting the dead space and ventilator rates. This eliminated the possible effect of different $\mathrm{PaCO}_{2}$ and $\mathrm{pH}$ on the results.
TNF- $\alpha$ is known for its ability to inhibit the TGF- $\beta$ dependent Smad2/3 pathway and CTGF expression (40). A recent study has demonstrated that antenatal endotoxin exposure increases expression of TGF- $\beta$ and $\mathrm{p}-\mathrm{Smad} 2$ but decreases CTGF expression in lungs of preterm lambs (41). The decreased CTGF expression was explained by the concurrent elevation of TNF- $\alpha$. In the present study, high $V_{\mathrm{T}}$ ventilation did not increase TNF- $\alpha$ expression. This may explain why high $V_{\mathrm{T}}$ ventilation induced significant expression of $\mathrm{p}-\mathrm{Smad} 2$ and CTGF in newborn rat lungs.

Our model did not intend to identify the downstream CTGF effects in response to high $V_{\mathrm{T}}$ because of the relatively short duration of ventilation. Recent data from our laboratory indicate that CTGF is a negative regulator of lung branching morphogenesis (27). CTGF is associated with TGF- $\beta$ induced fibroblast to myofibroblast differentiation that may interfere with secondary septal formation and alveolar development (15). In addition, CTGF is also a profibrotic cytokine that may result in interstitial fibrosis $(13,14)$. We speculate that prolonged overexpression of CTGF in the alveolar septa may inhibit alveolar development, produce interstitial fibrosis and result in BPD-like architecture in the immature lung.

In conclusion, the present study demonstrates that high $V_{\mathrm{T}}$ ventilation activates the Smad2 pathway and induces CTGF expression in newborn rat lungs. These results suggest an important role of this pathway in high $V_{\mathrm{T}}$ induced lung injury in neonates.

Acknowledgment. We thank Ms. Brenda Roberts for her excellent technical support on tissue preparation and immunohistochemistry.

\section{REFERENCES}

1. Jobe AH, Bancalari E 2001 Bronchopulmonary dysplasia. Am J Respir Crit Care Med 163:1723-1729

2. Attar MA, Donn SM 2002 Mechanisms of ventilator-induced lung injury in premature infants. Semin Neonatol 7:353-360

3. Donn SM, Sinha SK 2003 Can mechanical ventilation strategies reduce chronic lung disease? Semin Neonatol 8:441-448

4. Husain AN, Siddiqui NH, Stocker JT 1998 Pathology of arrested acinar development in postsurfactant bronchopulmonary dysplasia. Hum Pathol 29:710-717

5. Jobe AJ 1999 The new BPD: an arrest of lung development. Pediatr Res 46:641-643

6. Jonsson B, Tullus K, Brauner A, Lu Y, Noack G 1997 Early increase of TNF alpha and IL-6 in tracheobronchial aspirate fluid indicator of subsequent chronic lung disease in preterm infants. Arch Dis Child Fetal Neonatal Ed 77:F198-F201

7. Kotecha S, Wilson L, Wangoo A, Silverman M, Shaw RJ 1996 Increase in interleukin (IL)- $1 \alpha$ and IL-6 in bronchoalveolar lavage fluid obtained from infant with chronic lung disease of prematurity. Pediatr Res 40:250-256

8. Cao L, Liu C, Cai B, Jia X, Kang L, Speer CP, Sun B 2004 Nuclear factor-kappa B expression in alveolar macrophages of mechanically ventilated neonates with respiratory distress syndrome. Biol Neonate 86:116-123

9. Copland IB, Martinez F, Kavanagh BP, Engelberts D, Mckerlie C, Belik J, Post M 2004 High tidal volume ventilation causes different inflammatory responses in newborn versus adult lung. Am J Respir Crit Care Med 169:739-748

10. Bork P 1993 The modular architecture of a new family of growth regulator related to connective tissue growth factor. FEBS Lett 327:125-130

11. Grotendorst GR 1997 Connective tissue growth factor: a mediator of TGF-beta action on fibroblasts. Cytokine Growth Factor Rev 8:171-179

12. Leask A, Abraham DJ 2003 The role of connective tissue growth factor, a multifunctional matricellular protein, in fibroblast biology. Biochem Cell Biol 81:355363

13. Kothapalli D, Frazier KS, Welply A, Segarini PR, Grotendorst GR 1997 Transforming growth factor beta induces anchorage-independent growth of NRK fibroblasts via a connective tissue growth factor-dependent signaling pathway. Cell Growth Differ 8:61-68

14. Duncan MR, Frazier KS, Abramson S, Williams S, Klapper H, Huang X, Grotendorst GR 1999 Connective tissue growth factor mediates transforming growth factor beta-induced collagen synthesis: down-regulation by cAMP. FASEB J 13:17741786 
15. Grotendorst GR, Rahmanie H, Duncan MR 2004 Combinatorial signaling pathways determine fibroblast proliferation and myofibroblast differentiation. FASEB J 18:469-479

16. Crean JK, Finlay D, Murphy M, Moss C, Godson C, Martin F, Brady HR 2002 The role of p42/44 MARK and protein kinase B in connective tissue growth factor induced extracellular matrix protein production, cell migration, and actin cytoskeletal rearrangement in human mesangial cells. J Biol Chem 277:44187-44194

17. Lasky JA, Ortiz LA, Tonthat B, Hoyle GW, Corti M, Athas G, Lungarella G, Brody A, Friedman M 1998 Connective tissue growth factor mRNA expression is upregulated in bleomycin-induced lung fibrosis. Am J Physiol 275:L365-L371

18. Allen JT, Knight RA, Bloor CA, Spiteri MA 1999 Enhanced insulin-like growth factor binding protein-related protein 2 (Connective tissue growth factor) expression in patients with idiopathic pulmonary fibrosis and pulmonary sarcoidosis. Am J Respir Cell Mol Biol 21:693-700

19. Sato S, Nagaoka T, Hasegawa M, Tamatani T, Nakanishi T, Takigawa M, Takehara K 2000 Serum level of connective tissue growth factor are elevated in patients with systemic sclerosis: association with extent of skin sclerosis and severity of pulmonary fibrosis. J Rheumatol 27:149-154

20. Kessler D, Dethlefsen S, Haase I, Plomann M, Hirche F, Krieg T, Eckes B 2001 Fibroblasts in mechanically stressed collagen lattices assume a "synthetic" phenotype. J Biol Chem 276:36575-36585

21. Schild C, Trueb B 2002 Mechanical stress is required for high-level expression of connective tissue growth factor. Exp Cell Res 274:83-91

22. Grotendorst GR, Okochi H, Hayashi N 1996 A novel transforming growth factor beta response element controls the expression of the connective tissue growth factor gene. Cell Growth Differ 7:469-480

23. Blom IE, Goldschmeding R, Leask A 2002 Gene regulation of connective tissue growth factor: new targets for antifibrotic therapy? Matrix Biol 21:473-482

24. Kelly M, Kolb M, Bonniaud P, Gauldie J 2003 Re-evaluation of fibrogenic cytokines in lung fibrosis. Curr Pharm Des 9:39-49

25. Holmes A, Abraham DJ, Sa S, Xu S, Black CM, Leask A 2001 CTGF and SMADs, maintenance of scleroderma phenotype is independent of SMAD signaling. J Biol Chem 276:10594-10601

26. Leask A, Holmes A, Black CM, Abraham DJ 2003 Connective tissue growth factor gene regulation. Requirements for its induction by transforming growth factor-beta 2 in fibroblasts. J Biol Chem 278:13008-13015

27. Wu S, Peng J, Duncan MR, Kasisomayajula K, Grotendorst G, Bancalari E 2007 ALK-5 Mediates Endogenous and TGF-\{beta $\} 1$-induced Expression of CTGF in Embryonic Lung. Am J Respir Cell Mol Biol 36:552-561
28. Chen CM, Wang LF, Chou HC, Lang YD, Lai YP 2007 Up-regulation of connective tissue growth factor in hyperoxia-induced lung fibrosis. Pediatr Res 62:128-133

29. Lessa A, Suguihara C, Xianyu S, Hehre D, Devia C, Bancalari E The effect of pentoxifyline on the pulmonary response to high tidal volume ventilation in rats. Pulm Pharmacol Ther (in press).

30. Wu S, Moomaw CR, Tomer KB, Falck JR, Zeldin DC 1996 Molecular cloning and expression of CYP2J2, a human cytochrome P450 arachidonic acid epoxygenase highly expressed in heart. J Biol Chem 271:3460-3468

31. Ruperez M, Lorenzo O, Blanco-Colio LM, Esteban V, Egido J, Ruiz-Ortega M 2003 Connective tissue growth factor is a mediator of angiotensin II-induced fibrosis. Circulation 108:1499-1505

32. Dong C, Zhu S, Wang T, Yoon W, Goldschmidt-Clermont PJ 2002 Upregulation of PAI-1 is mediated through TGF-beta/Smad pathway in transplant arteriopathy. J Heart Lung Transplant 21:999-1008

33. Coalson JJ, Winter VT, Siler-Khodr T, Yoder BA 1999 Neonatal chronic lung disease in extremely immature baboons. Am J Respir Crit Care Med 160:1333-1346

34. Bland RD, Xu L, Ertsey R, Rabinovitch M, Albertine KH, Wynn KA, Kumar V, Ryan RM, Swartz DD, Csiszar K, Fong KS 2007 Dysregulation of pulmonary elastin synthesis and assembly in preterm lambs with chronic lung disease. Am J Physiol Lung Cell Mol Physiol 292:L1370-L1384

35. Massaro GD, Massaro D 1996 Formation of pulmonary alveoli and gas-exchange surface area: quantitation and regulation. Annu Rev Physiol 58:73-92

36. Coalson JJ 2006 Pathology of bronchopulmonary dysplasia. Semin Perinatol 30:179-184

37. Burri PH 1997 Postnatal development and growth. In Crystal RG, West JB (eds). The Lungs: Scientific Foundations. 2nd ed. Lippincott-Raven Publishers, Philadephia, pp 1013-1026

38. Zoetis T, Hurtt ME 2003 Species comparison of lung development. Birth Defects Res B Dev Reprod Toxicol 68:121-124

39. Heldin CH, Miyazono K, Dijke P 1997 TGF-beta signaling from cell membrane to nucleus through SMAD proteins. Nature 390:465-471

40. Leask A, Abraham DJ 2004 TGF- $\beta$ signaling and the fibrotic response. FASEB J 18:816-827

41. Kunzmann S, Speer CP, Jobe AH, Kramer BW 2007 Antenatal inflammation induced TGF-beta1 but suppressed CTGF in preterm lungs. Am J Physiol Lung Cell Mol Physiol 292:L223-L231 